Transactions of the American Fisheries Society, Volume 117, Issue 2 (March 1988), pp. $142-151$.

Online ISSN: 1548-8659

Print ISSN: 0002-8487

http://afs.allenpress.com

http://afs.allenpress.com/archive/1548-8659/117/2/pdf/i1548-8659-117-2-142.pdf DOI: 10.1577/1548-8659(1988)117<0142:SPBTET>2.3.CO;2

(C) American Fisheries Society 


\title{
Selective Predation by Three Esocids: The Role of Prey Behavior and Morphology
}

\author{
David H. Wahl and Roy A. Stein \\ Ohio Cooperative Fish and Wildlife Research Unit' and \\ Department of Zoology. The Ohio State University. 1735 Neil Avenue \\ Columbus, Ohio 43210. USA
}

\begin{abstract}
We documented differential vulnerability of fathead minnows Pimephales promelas, gizzard shad Dorosoma cepedianum, and bluegills Lepomis macrochirus to predation by muskellunge Esox masquinongy, northern pike $E$. lucius, and tiger muskellunge $E$. masquinongy $\times E$. lucius in a 700-L tank. Individual esocids (150-225 mm in total length) were combined with singlespecies groups $(N=15)$ of optimal-sized prey $(25-30 \%$ of predator length for bluegills, $37-43 \%$ for fathead minnows, and 30-36\% for gizzard shad). Capture ability did not differ among esocids; however, mean captures per strike were higher for fathead minnow (0.67) and gizzard shad $(0.78)$ than for bluegill (0.14). Morphology and antipredatory behavior, unique to each prey species, contributed to this differential vulnerability. In the field, we introduced equal numbers and similar sizes of these esocids into two systems, one with centrarchid prey and one with both centrarchid and gizzard shad prey. As predicted from laboratory work, esocids ate fewer prey and grew more slowly when centrarchids were the only prey than they did when gizzard were available. In a third reservoir, containing bluegills and gizzard shad, esocids strongly preferred gizzard shad over bluegills. To maximize growth and survival, esocids should be stocked in systems with soft-rayed or fusiform prey, such as cyprinids or shad, rather than in centrarchid-dominated systems.
\end{abstract}

Muskellunge Esox masquinongy, northern pike $E$. lucius, and their hybrid, tiger muskellunge $E$. masquinongy $\& \times E$. lucius $\delta$, are important sport fishes stocked throughout the United States. Prey available for these fishes influences their survival and growth after stocking (Carline et al. 1986). For the hybrid, growth is slower in impoundments predominated by bluegill Lepomis macrochirus than in systems containing gizzard shad Dorosoma cepedianum (Weithman and Anderson 1977; Goddard and Redmond 1978; Carline et al. 1986; Newman and Storck 1986) or fathead minnow Pimephales promelas (Gillen et al. 1981; Tomcko et al. 1984). However, comparisons of tiger muskellunge growth between gizzard shad and bluegill systems must be interpreted with caution, because differences in prey density (Tomcko et al. 1984) and size (Gillen et al. 1981) influence feeding rates of the hybrid. Laboratory experiments have confirmed field observations; tiger muskellunge select gizzard shad in preference to bluegills (Weithman and Anderson 1977). Moody et al. (1983) explained some of the low selectivity for bluegills by showing that tiger muskellunge required four times as many strikes and longer pursuits to capture bluegills than to capture fathead minnows.

\footnotetext{
1 The unit is sponsored jointly by the U.S. Fish and Wildlife Service, the Ohio Department of Natural Resources, The Ohio State University, and the Wildlife Management Institute.
}

Although the nature of prey selection by tiger muskellunge is well documented, the foraging behavior of the two parent species is not well known. Though bluegills are not their preferred prey, northern pike will consume bluegills in ponds and lakes when these prey are abundant (Johnson 1969; Beyerle 1971; Headrick 1985). Northern pike grow at similar rates whether they eat bluegills or fathead minnows, but they survive less well on a bluegill diet (Beyerle 1978). In contrast, laboratory work suggests northern pike choose gizzard shad, common carp Cyprinus carpio, and minnows over centrarchids (Beyerle and Williams 1968; Mauck and Coble 1971; Weithman and Anderson 1977). Laboratory experiments evaluating prey selection by muskellunge are contradictory. Weithman and Anderson (1977) found that all three esocids exhibited similar prey selection, whereas Engstrom-Heg et al. (1986) found that northern pike and tiger muskellunge, but not muskellunge, show prey selectivity. None of these laboratory studies controlled for optimal prey size (prey size with minimal ratio of esocid handling time per unit of dry weight of prey; that is, with a minimal cost : benefit ratio; Gillen et al. 1981), making both comparisons among prey species and inferences about natural situations difficult.

We designed a study to compare mechanisms of prey selection among tiger muskellunge, muskellunge, and northern pike in the laboratory and to test these predictions in field experiments. To 
avoid deficiencies observed in previous work, we presented predators in the laboratory with prey of optimal size and we documented prey densities and size distributions in the field.

\section{Methods}

Laboratory experiments. - We conducted 225 $\mathrm{l}$-h observational experiments in a $700-\mathrm{L}$ tank $(260 \times 53 \times 60 \mathrm{~cm})$ at water temperatures of 18 $23^{\circ} \mathrm{C}$ and a photoperiod of $14 \mathrm{~h}$ light : $10 \mathrm{~h}$ darkness. The tank was divided into a predator-holding chamber $(50 \times 53 \mathrm{~cm})$ and an experimental chamber $(210 \times 53 \mathrm{~cm})$ by an opaque divider and a remotely controlled door. Prey were added to the experimental chamber $24 \mathrm{~h}$ before each experiment. Esocids were obtained from Ohio Division of Wildlife fish hatcheries, whereas prey were collected from local ponds, reservoirs, and fish hatcheries. Individual northern pike, muskellunge, and tiger muskellunge $(150-225 \mathrm{~mm}$ in total length) were combined with optimal sizes of naive single-species groups $(N=15)$ of fathead minnows, bluegills, and gizzard shad. Optimal sizes of prey were based on laboratory experiments (Gillen et al. 1981) for bluegills (25-30\% of predator length) and fathead minnows (37-43\%), and from field data (Carline et al. 1986) for gizzard shad (30-36\%). Esocids, conditioned to the appropriate prey for at least 2 weeks, were added to the holding chamber and starved for $24 \mathrm{~h}$ before each experiment. Experiments began as the remotely controlled door was opened and an esocid entered the experimental chamber.

After predator release, we quantified predator and prey behavior. Esocid behaviors were separated into seven mutually exclusive categories. as described by Webb and Skadsen (1980), Savino and Stein (1982), and Moody et al. (1983):

search: moving, but not orienting to prey: follow: moving, and orienting to particular prey; pursue: following at burst speed;

attack: striking at prey;

capture: grasping prey;

inactive: resting and motionless, not oriented toward prey;

observe: motionless, but oriented to an individual

prey, with caudal and dorsal fins typically beat-

ing rapidly.

Capture efficiency during each experiment was calculated as the number of captures divided by the number of attacks. Handling times (s) for prey were recorded as the period between capture and complete ingestion ("handling time" is defined as the elapsed time between grasping and swallowing of prey). Esocid behaviors were coded directly into a Datamyte event recorder (Electro/General Corporation, Minnetonka, Minnesota); entries were made with each change in behavior, providing a record of the number of occurrences and time spent in each behavior.

Prey behavior and position were recorded every $2 \min (N=30$ observations per experiment); mean values for each experiment were used in treatment comparisons. At each observation, we recorded the number of prey either schooling (individuals aggregated and moving as a unit) or dispersed (individuals not aggregated and not moving as a unit), and the distance from the closest schooled and dispersed prey individual to the predator (nearest $1 \mathrm{~cm})$. Distances were estimated with grids $(1-\mathrm{cm}$ intervals) marked on the front and back of the tank. Behavior and initial distance from the predator for prey attacked were compared with similar data for prey not attacked.

We tested five individuals of each esocid taxon, replicated three to seven $(80 \%$ were replicated at least five times) times, against each of the three prey species. These replicates provided 25 experiments per predator by prey treatment. To avoid problems associated with pseudoreplication (Hurlbert 1984), we compared means for each individual esocid. Except where indicated, statistical analyses involved two-way analysis of variance and Tukey's multiple comparisons (Montgomery 1984; SAS 1985).

Field experiments. - To evaluate our laboratory findings, we stocked equal numbers and sizes of tiger muskellunge, muskellunge, and northern pike into three Ohio impoundments (Table 1) in August or September. After each stocking, we collected fish by electrofishing the perimeter of the reservoir every 2 weeks through mid-December. We measured total length (nearest millimeter) and weight (nearest gram) and obtained stomach contents by pulsed gastric lavage (Foster 1977).

Two stockings, in North Reservoir (Summit County, Ohio) and Tobin's Pond (Madison County, Ohio), permitted growth and feeding rate comparisons of esocids with and without gizzard shad. The centrarchid-only system, Tobin's Pond, contained stunted bluegills with densities comparable to those of gizzard shad in Ohio reservoirs (Johnson et al. 1988, this issue). Esocids were stocked at somewhat higher densities in Tobin's Pond than in North Reservoir, but prey densities also were higher there (Table 1). Inshore, littoral densities and size distributions of young-of-year prey were 
TABLE 1.-Summary of tiger muskellunge, muskellunge, and northern pike stockings in three Ohio reservoirs. Mean lengths (mm) and inshore, littoral densities of young-of-year prey (bluegill, gizzard shad) at time of stocking were estimated by standard seine hauls (adjusted by seine versus quadrat rotenone efficiency for gizzard shad) in Tobin's Pond and North Reservoir and by quadrat (0.15 hectare) rotenone samples (Johnson et al. 1988) in Kokosing Reservoir. $\mathrm{Cl}$ is confidence interval.

\begin{tabular}{|c|c|c|c|c|c|c|c|}
\hline \multirow[b]{4}{*}{ Systcm (hectares) } & \multirow[b]{4}{*}{ Stocking datc } & \multirow{4}{*}{$\begin{array}{l}\text { Water } \\
\text { temper- } \\
\text { ature } \\
\left({ }^{\circ} \mathrm{C}\right)\end{array}$} & \multirow{2}{*}{\multicolumn{2}{|c|}{ Esocid characteristics }} & \multicolumn{3}{|c|}{ Prey characteristics } \\
\hline & & & & & \multirow{2}{*}{\multicolumn{2}{|c|}{ Mean length $(95 \% \mathrm{CI})$}} & \multirow{3}{*}{$\begin{array}{l}\text { Total } \\
\text { young-of- } \\
\text { year prey } \\
\text { density. } \\
\text { number ' } \mathrm{m}^{-2} \\
(95 \% \mathrm{CI})\end{array}$} \\
\hline & & & \multirow{2}{*}{$\begin{array}{l}\text { Number of } \\
\text { each esocid } \\
\text { taxon per } \\
\text { hectare }\end{array}$} & \multirow{2}{*}{$\begin{array}{l}\text { Mean total } \\
\text { length, mm } \\
(95 \% \mathrm{CI})\end{array}$} & & & \\
\hline & & & & & Bluegill & Gizzard shad & \\
\hline Tobin's Pond (2.2) & 25 Sep 1983 & 20 & 43 & $219( \pm 3.6)$ & $31.2( \pm 1.7)$ & & $9.6( \pm 3.7)$ \\
\hline North Reservoir (89) & 28 Aug 1985 & 25 & 24 & $206( \pm 4.4)$ & $41.7( \pm 0.6)$ & $59.1( \pm 1.6)$ & $4.8( \pm 3.3)$ \\
\hline Kokosing Reservoir (65) & 10 Aug 1984 & 27 & 18 & $146( \pm 3.1)$ & $36.5( \pm 1.1)$ & $38.4( \pm 3.9)$ & $6.4( \pm 3.4)$ \\
\hline
\end{tabular}

estimated in the first week after stocking by seine hauls $(9 \times 1.8-\mathrm{m}$ bag seine, $6.4-\mathrm{mm}$ mesh) at five sites ( $15 \mathrm{~m}$ of shoreline) on $5 \mathrm{~d}$ in North Reservoir and at three sites on $4 \mathrm{~d}$ in Tobin's Pond. All prey were identified and counted, and at least 20 of each species per site were measured (nearest millimeter). Because seining underestimates gizzard shad abundance, we used relative efficiencies of seining versus rotenone samples to adjust seine estimates of gizzard shad densities in North Reservoir (as per Johnson et al. 1988). Centrarchid densities estimated by seine and rotenone sampling were similar. Cyprinid species were excluded because their densities were extremely low $(<0.5 \%$ of all prey). Though centrarchid and gizzard shad lengths in the field were not always within the narrow range chosen for laboratory experiments, both prey types were still near optimal sizes in all field experiments (Table 1; Gillen et al. 1981; Carline et al. 1986). After stocking, we sampled prey populations on dates corresponding to esocid collections. Prey densities remained similar between the two systems through fall, and prey lengths stayed within appropriate ranges. Because of the different stocking dates for the two systems, water temperatures (measured at a depth of $1 \mathrm{~m}$ ) differed at stocking (Table 1), but thereafter were similar between systems.

In a third stocking in Kokosing Reservoir (Knox County, Ohio), we evaluated prey preference directly by comparing esocid diets with prey abundance during three sampling intervals. Our index was Chesson's (1983) alpha:

$$
\alpha_{i}=\frac{r_{i} / n_{i}}{\left(r_{1} / n_{1}\right)+\ldots+\left(r_{m} / n_{m}\right)}, \quad i=1, \ldots, m ;
$$

$m$ is the number of food types (two in this case) and $r_{i}$ and $n_{i}$ are the proportions of food type $i$ in the diet and environment, respectively. The re- sulting index ranges from 0 to +1 , and 0.5 represents no preference. Density and length estimates for all available prey (exclusive of cyprinids) were determined by rotenone sampling of 0.15 hectare quadrats $(N=18)$ isolated by plastic barriers $(2.1 \times 122 \mathrm{~m}$, with float line and lead line). Johnson et al. (1988) set these barriers, anchored on shore and paid out from a boat, in the form of a rectangle delineated by posts in the substrate. They placed six bottom nets $(1.7 \times 26 \mathrm{~m}, 5-\mathrm{mm}$ mesh) at regular intervals within each quadrat $(18 \%$ of quadrat area) and applied synergized liquid rotenone $(2 \mathrm{mg} / \mathrm{L})$ to the quadrat. Prey were recovered after $1 \mathrm{~h}$ by lifting bottom nets (Johnson et al. 1988).

\section{Results}

\section{Laboratory Experiments}

Prey capture efficiency was similar among individual predators within a taxon (nested analysis of variance: $F=0.91, \mathrm{df}=36,90, P=0.61$ ) and among the three esocid taxa $(F=1.21, \mathrm{df}=2,36$, $P=0.31$; Figure 1$)$. Indeed, esocids did not differ in any behavior quantified in experiments $(P=$ $0.2-0.7)$. We also observed no interaction between esocid taxa and prey species treatments $(P=0.15$ 0.85 ). However, esocids attacked more bluegills (mean, $5.8 ; 95 \%$ confidence interval, \pm 1.1 ) per experiment than either of the other prey; they also attacked more fathead minnows $(3.2 \pm 1.1)$ than gizzard shad $(1.4 \pm 1.0)(F=18.88, \mathrm{df}=2,36$, $P<0.001$; Tukey's multiple comparisons: $T=$ 1.74, $P<0.05$ ). Number of prey consumed per experiment followed a different pattern, being higher for fathead minnow $(1.9 \pm 0.3)$ than for either gizzard shad $(1.0 \pm 0.3)$ or bluegill $(0.5 \pm$ 0.4) $(F=25.45$, df $=2,36, P<0.001 ; T=0.52$, $P<0.05)$. Mean captures per strike were higher 


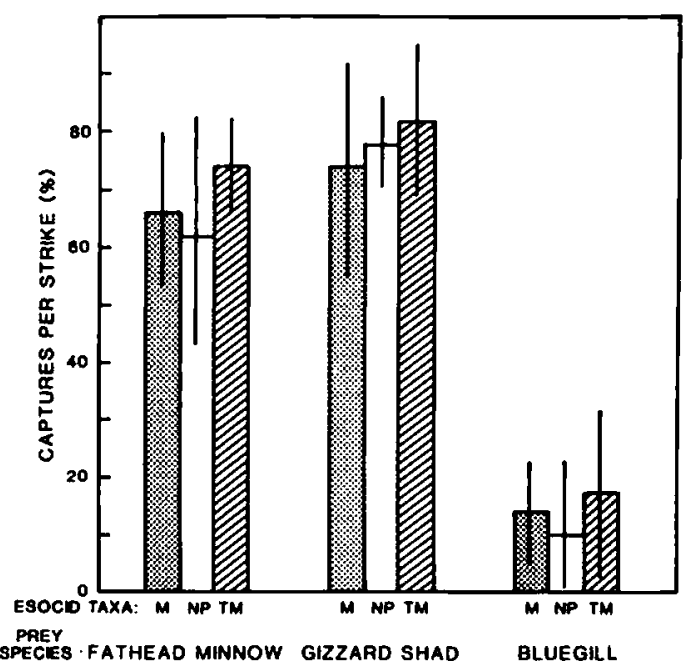

Figure 1.-Capture efficiency (captures per strike) for muskellunge (M), northern pike (NP), and tiger muskellunge (TM) feeding on fathead minnows, gizzard shad, and bluegills. Mean values are based on five individuals of each esocid taxon, each replicated three to seven times, for each of the three prey species. Vertical lines represent $95 \%$ confidence intervals.

for fathead minnow (0.67) and gizzard shad (0.78) than for bluegill (0.14) $(F=66.24, \mathrm{df}=2,36, P$ $<0.001 ; T=0.13, P<0.05$; Figure 1).

To explain differences in predatory success, we compared the time spent by esocids in each of the five behaviors of the predation sequence leading to an attack on each of the three prey species (Figure 2). We found no differences in any of the behaviors among the esocid taxa, and present only combined data for the three. More time was spent on observing prey and on energetically costly behaviors (following and pursuing) when bluegills were prey than when fathead minnows or gizzard shad were prey $(\mathrm{df}=2,36, P<0.05)$. Time spent inactive and searching (Figure 2) were similar in the presence of the three prey species $(\mathrm{df}=2,36$, $P>0.05$ ); esocids did not appear to compensate for reduced captures of bluegills by increased searching.

Morphological differences and antipredatory behavior patterns among the prey affected their differential vulnerability. Esocids captured fewer bluegills in the midbody region than either fathead minnows or gizzard shad (Table 2; chi-square, partitioned degrees of freedom: $P<0.05$ ). Handling times were also higher for captured bluegills, followed by those for gizzard shad and fathead minnow $(F=3.62$, df $=2,36, P<0.05 ; T=$ $2.27, P<0.05$; Figure 3 ). Fathead minnows spent

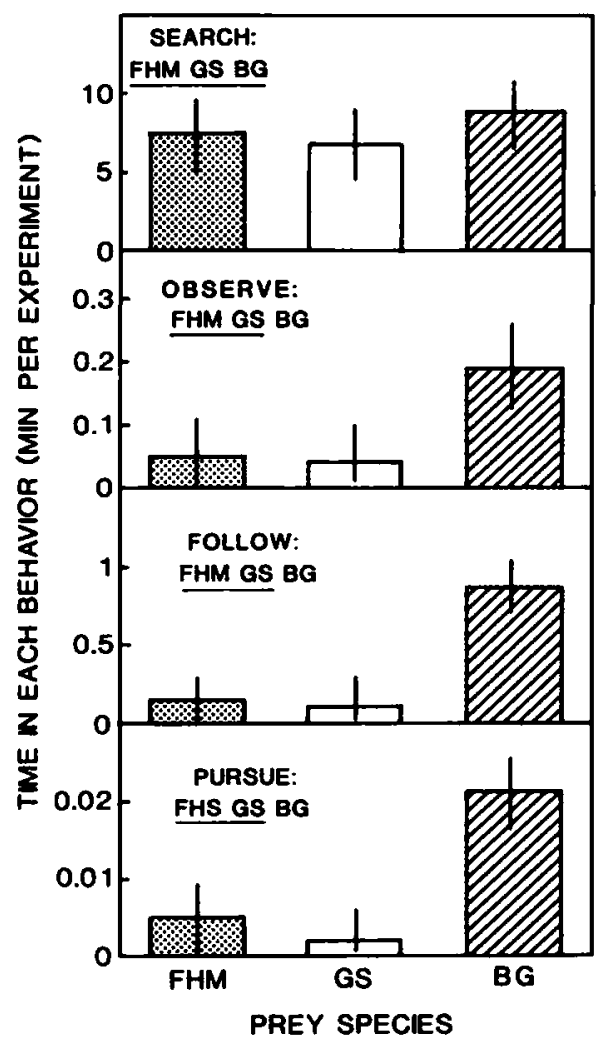

FIGURE 2.-Time spent in predatory behaviors by esocids feeding on fathead minnows (FHM), gizzard shad (GS), and bluegills (BG) during a l-h experiment. Means not different from one another share an underline (analysis of variance: $d f=2,36$; Tukey's multiple comparisons: $P>0.05)$. Vertical lines represent $95 \%$ confidence intervals.

more time in schools than did other prey species (Table 3; one-way analysis of variance: $F=12.82$, df $=2,222, P<0.001$ ), although all three prey schooled most of the time; schooling differences did not result in differences in predator capture efficiency. Bluegills spent more time actively avoiding predators; the distance from the predator to both the closest dispersed prey (one-way analysis of variance: $F=55.84, \mathrm{df}=2,222, P<0.001$ ) and closest schooled prey $(F=64.71, \mathrm{~d} f=2,222$, $P<0.001$ ) was greater for bluegill than for either of the other two prey (Table 3). Schooled and solitary gizzard shad maintained similar distances from the esocids (paired $t$-test: $P=0.34$ ), whereas schooled fathead minnows and bluegills remained farther from the predators than did solitary individuals $(P<0.05)$. Distances from the predator alone did not account for patterns of attacks on dispersed and schooled prey of the three species. 
Esocids attacked more schooled than dispersed fathead minnows and gizzard shad (Table 3; paired t-test, $P<0.05$ ) but similar numbers of schooled and dispersed bluegills $(P=0.26)$. The greater distances maintained from the predator by bluegills may explain some of the longer pursuing and following times for these prey. Distances swum by predators when following prey were similar regardless of prey dispersion, but were longer for bluegills than for fathead minnows or gizzard shad (Table 3; one-way analysis of variance: $F=30.71$, df $=2,222, P<0.001: T=6.99, P<0.05$ ).

\section{Field Experiments}

As predicted from laboratory experiments, feeding and growth of all three esocid taxa were less in a centrarchid-dominated system than in a system with alternative prey. Percent empty stomachs was higher in Tobin's Pond, which contained bluegills but not gizzard shad, than in North Reservoir, where gizzard shad occurred (Table 4). Differences between impoundments were greatest for all three taxa in September and October: November differences were not significant primarily due to small sample sizes in Tobin's Pond. When we combined data for all 3 months, percentages of empty stomachs were higher when bluegills were the only prey for all esocids (chi-square: $P<0.005$ ). Growth of northern pike and tiger muskellunge through fall was slower in Tobin's Pond than in North Reservoir (analysis of covariance, homogeneity of slope: $P<0.05$; Figure 4 ) whereas growth of muskellunge did not differ between the two systems $(P=0.12)$. Again, patterns were less clear for muskellunge, primarily because few muskellunge were captured in Tobin's Pond. Survival, as indicated by catch per unit effort, was lower for all esocid taxa in Tobin's Pond: despite extensive sampling. catches declined to near zero by early November. In contrast, catches remained high through fall into spring in North Reservoir.

TABLE 2.-Body area struck by esocids feeding on fathead minnows, gizzard shad, and bluegills. Values with the same letter within a row. or column, or both, do not differ (chi-square, partitioned degrees of freedom: $P>$ 0.05 ). Total number of captures $(N)$ is indicated for each prey species.

\begin{tabular}{lrlcl}
\hline & & \multicolumn{3}{c}{ Capture location (\%) } \\
\cline { 3 - 5 } \multicolumn{1}{c}{ Prey species } & $N$ & Head & $\begin{array}{c}\text { Caudal } \\
\text { area }\end{array}$ & $\begin{array}{c}\text { Mid- } \\
\text { body }\end{array}$ \\
\hline Fathead minnow & 158 & $13 z$ & $20 \mathrm{zx}$ & $67 \mathrm{y}$ \\
Gizrard shad & 90 & $12 \mathrm{z}$ & $16 \mathrm{zx}$ & $72 \mathrm{y}$ \\
Bluegill & 50 & $26 \mathrm{zx}$ & $34 \mathrm{zx}$ & $40 \mathrm{x}$ \\
\hline
\end{tabular}

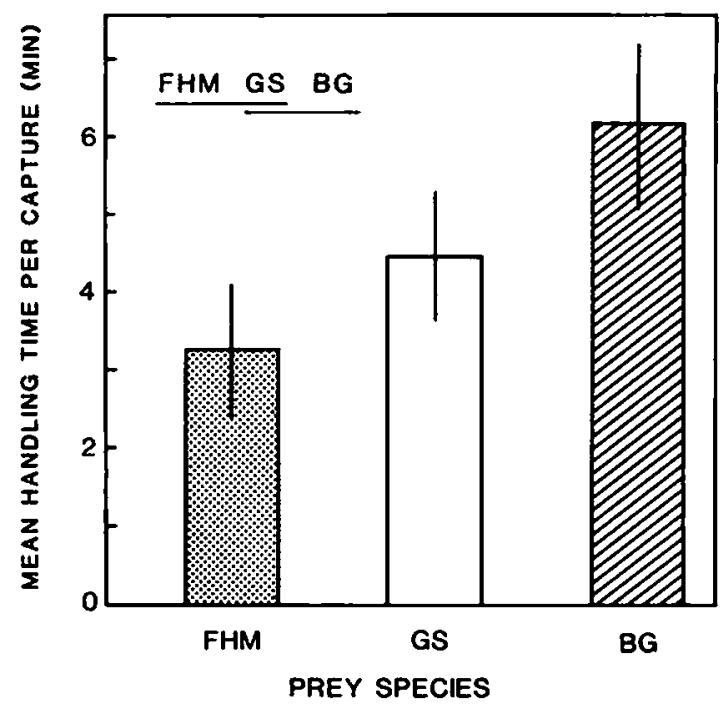

Figure 3. - Mean handling times for esocids $(N=15$ per prey treatment) capturing fathead minnows (FHM), gizzard shad (GS). and blucgills (BG). Means not different from one another share an underline $(F=3.62$, df $=2$. 36; Tukey's multiple comparisons: $T=2.27, P>$ 0.05 ). Vertical lines represent $95 \%$ confidence intervals.

In the second field experiment in Kokosing Reservoir. we directly compared prey preferences among the three esocids. Gizzard shad densities (number $\cdot \mathrm{m}^{-2}$ ) exceeded centrarchid densities for all three quadrat rotenone-sampling intervals. Because diets did not differ among the three esocids (chi-square: $P>0.25$ ), data were combined across taxa. As predicted, esocids strongly preferred gizzard shad and not bluegills (Table 5).

\section{Discussion}

In previous work by others, muskellunge, northern pike, and tiger muskellunge preferred gizzard shad and minnows over centrarchids (Beyerle and Williams 1968; Mauck and Coble 1971; Coble 1973; Weithman and Anderson 1977). We found that esocids exhibit a similar pattern of prey selection in the field; all three taxa preferred gizzard shad over centrarchids. Our laboratory experiments provide a mechanistic explanation for these patterns. Capture efficiency and time required for capture differed among prey; bluegills required esocids to spend longer periods following and pursuing them, and to make five times as many strikes to capture them, than did either fathead minnows or gizzard shad. Consistent with previous evaluations of capture success by tiger muskellunge feeding on fathead minnows and bluegills (Webb and Skadsen 1980; Moody et al. 
TABLE 3.-Comparisons of prey behavior (recorded at 2-min intervals), of the number of prey attacked, and of the distance prey were followed by three esocid predators (combined data) during each 1 -h experiment ( $N=75$ per prey treatment). Numbers in parentheses are $95 \%$ confidence intervals. Row values with the same letter do not differ (analysis of variance and Tukey's multiple comparisons; $P>0.05$ ).

\begin{tabular}{|c|c|c|c|}
\hline \multirow[b]{2}{*}{ Measurement } & \multicolumn{3}{|c|}{ Prey species } \\
\hline & Fathead minnow & Gizzard shad & Bluegill \\
\hline \multicolumn{4}{|c|}{ Prey behavior } \\
\hline $\begin{array}{l}\text { Percent of time schooled } \\
\text { Distance to esocid }(\mathrm{cm})\end{array}$ & $90.9( \pm 4.5) \mathrm{z}$ & $71.8( \pm 8.6) y$ & $73.1( \pm 5.9)$ y \\
\hline $\begin{array}{l}\text { Closest dispersed } \\
\text { Closest schooled }\end{array}$ & $\begin{array}{l}35.0( \pm 4.3) z \\
76.0( \pm 6.1) z\end{array}$ & $\begin{array}{l}32.0( \pm 2.7) z \\
37.0( \pm 5.3) y\end{array}$ & $\begin{array}{l}57.0( \pm 4.0) y \\
88.0( \pm 5.7) x\end{array}$ \\
\hline \multicolumn{4}{|c|}{ Mean number of prey attacked } \\
\hline $\begin{array}{l}\text { Schooled } \\
\text { Dispersed }\end{array}$ & $\begin{array}{l}2.6( \pm 0.7) z \\
0.7( \pm 0.2) z\end{array}$ & $\begin{array}{l}1.0( \pm 0.3) y \\
0.5( \pm 0.2) 7\end{array}$ & $\begin{array}{l}2.5( \pm 0.9) z \\
3.2( \pm 1.2) y\end{array}$ \\
\hline \multicolumn{4}{|c|}{ Distance prey followed by predators } \\
\hline Distance to prey $(\mathrm{cm})$ & $23.0( \pm 3.3) z$ & $17.0( \pm 3.0) z$ & $38.0( \pm 5.1) y$ \\
\hline
\end{tabular}

1983), time and (presumed) energy expenditure required for a capture appeared directly related to prey preference.

The three esocids did not differ in their preycapture ability in either laboratory or field (as Weithman and Anderson 1977 documented in ponds). By contrast, in 11 laboratory experiments $(6,2$, and 3 for tiger muskellunge, northern pike, and muskellunge, respectively) involving prey that were $10-36 \%$ of the length of the predators, Engstrom-Heg et al. (1986) found that tiger muskellunge and northern pike, but not muskellunge, selected white suckers Catostomus commersoni and golden shiners Notemigonus crysoleucas over yellow perch Perca flavescens. Selection by tiger muskellunge and northern pike for cylindrical, soft-

TABLE 4. - Percent empty stomachs ( $\pm 95 \%$ confidence interval) for northern pike (NP), tiger muskellunge (TM), and muskellunge (M) in Tobin's Pond (bluegills were the only prey) and North Reservoir (prey were gizzard shad and bluegills). Percent empty stomachs differed between the two systems for each taxon in September and October (chi-square; $P \leq 0.02$ ), but did not differ in November (chi-square: $P=0.2-0.7$ ).

\begin{tabular}{cccccrc}
\hline & & \multicolumn{2}{c}{ Tobin's Pond } & & \multicolumn{2}{c}{ North Reservoir } \\
\cline { 3 - 4 } \cline { 6 - 7 } Month & $\begin{array}{c}\text { Esocid } \\
\text { taxon }\end{array}$ & $N$ & $\begin{array}{c}\text { Percent } \\
\text { cmpty }\end{array}$ & & $N$ & $\begin{array}{c}\text { Percent } \\
\text { empty }\end{array}$ \\
\hline Sep & NP & 41 & $90( \pm 9)$ & & 139 & $60( \pm 8)$ \\
& TM & 40 & $95( \pm 7)$ & & 150 & $59( \pm 8)$ \\
& $M$ & 43 & $95( \pm 7)$ & & 42 & $72( \pm 14)$ \\
Oct & NP & 41 & $83( \pm 12)$ & & 115 & $33( \pm 9)$ \\
& TM & 29 & $72( \pm 16)$ & & 21 & $22( \pm 18)$ \\
& $M$ & 13 & $92( \pm 15)$ & & 73 & $44( \pm 8)$ \\
Nov & NP & 10 & $60( \pm 30)$ & & 136 & $32( \pm 8)$ \\
& TM & 10 & $40( \pm 30)$ & & 38 & $26( \pm 14)$ \\
& $M$ & 2 & $50( \pm 49)$ & & 67 & $40( \pm 12)$ \\
\hline
\end{tabular}

rayed fish over spiny-rayed ones is consistent with our work; Engstrom-Heg et al.'s (1986) anomalous results with muskellunge may derive from unique behavioral patterns of the prey used, inadequate sample size, or inappropriate predator: prey size ratios.

Antipredator behaviors of prey contribute to differential capture success by esocids. Bluegills typically outmaneuver predators, whereas fathead minnows and gizzard shad rely on speed and schooling (Moody et al. 1983; Tomcko et al. 1984; Webb 1986). In our experiments, all three prey spent the majority of their time schooled. Savino and Stein (1982, in press) observed flexible dispersal patterns by bluegills and schooling of bluegills at low vegetation densities similar to behaviors observed in our experiments. Schooling is thought to make it difficult for a predator to single out and attack an individual (Neill and Cullen 1974), allowing schooling prey to respond to an attack more effectively than solitary prey (Radakov 1973). Esocids attacked fewer schooling bluegills than either schooling gizzard shad or fathead minnows, another indication of the difficulty these predators had in capturing bluegills. Bluegills also maintained greater distances from esocids than either fathead minnows or gizzard shad. In addition, Howick and O'Brien (1983) and Savino and Stein (in press) described "back-peddling," dartand-freeze escape, and perpendicular orientation of bluegills to predators, behaviors that we commonly observed in our experiments. These behaviors either maximize distances between predator and prey, providing opportunity for escape, or maximize apparent body size. Both the faster acceleration (Webb 1986) and smaller turning ra- 


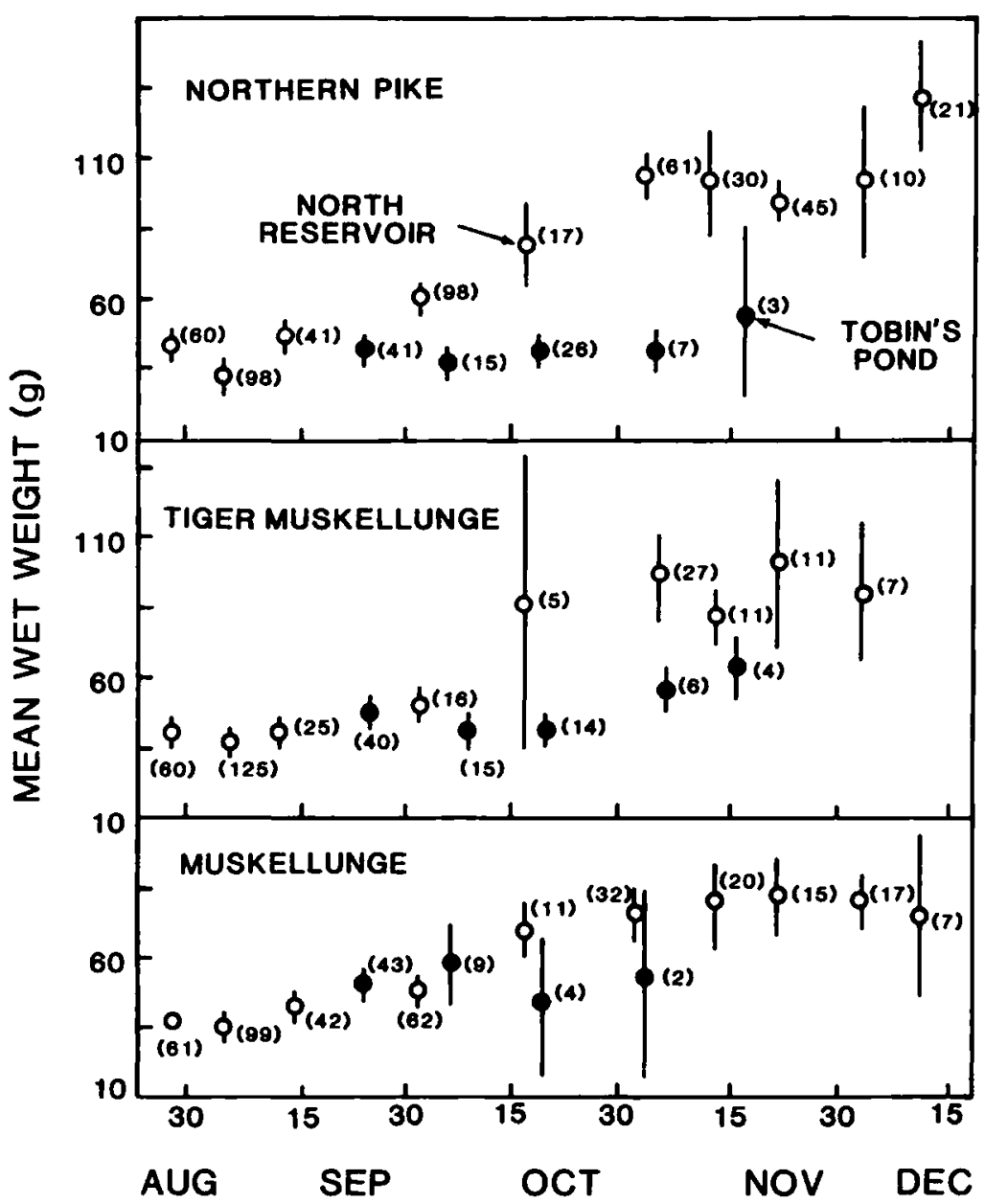

Figure 4. - Growth (weight) of three esocids in Tobin's Pond (solid circles) and North Reservoir (open circles), Ohio. Numbers of fish sampled are in parentheses. Tobin's Pond contained only bluegills whereas North Reservoir contained both bluegills and gizzard shad. Circles represent mean values, and vertical lines represent $95 \%$ confidence intervals.

dius (Howland 1974) of bluegills, compared to other prey, appear to reduce predators' capture success. In contrast to these antipredator behaviors, fathead minnows and gizzard shad relied exclusively on schooling to avoid predation.

Body depth and the presence of spines affected prey-handling times in our experiments. Esocids handled the cylindrical and soft-rayed fathead minnows more quickly than the deep-bodied bluegills or gizzard shad. Webb (1986) found that captures of fathead minnows and bluegills by largemouth bass Micropterus salmoides were only successful when strikes were made near the center of mass of the prey. Capture success by our esocids, and the proportions of midbody captures, were higher for fathead minnows and gizzard shad than for bluegills. The dorsal spines of bluegills may redirect attacks from the midbody to the caudal and head areas (Moody et al. 1983). In contrast, by comparing attacks by largemouth bass predators on largemouth bass and bluegill prey, Webb (1986) concluded that body depth, not spines, affects predator target selection. In our experiments, midbody captures differed between gizzard shad (without spines) and bluegills (with spines), two species with similarly compressed body shapes. In Reist's (1980) experiments, northern pike chose phenotypes of brook stickleback Culaea inconstans with the fewest spines. Thus, both dorsal spines and body depth of prey seem important in determining strike target and capture success by esocids. Previous work also indicates that spines 
TABLE 5. - Prey preference (Chesson's alpha $\pm 95 \%$ confidence interval) by three esocid taxa during three intervals in Kokosing Reservoir, Ohio. Young-of-year prey densities (average number $\cdot \mathrm{m}^{-2} \pm 95 \%$ confidence interval) were estimated by 0.15 -hectare quadrat rotenone samples (Johnson et al. 1988). $P$-values are for a $t$-test of the null hypothesis of no preference (Chesson 1983).

\begin{tabular}{|c|c|c|c|c|c|c|c|}
\hline \multirow{2}{*}{$\begin{array}{l}\text { Sampling } \\
\text { interval }\end{array}$} & \multirow{2}{*}{$\begin{array}{l}\text { Quadrats } \\
\text { sampled }\end{array}$} & \multicolumn{2}{|c|}{ Prey density } & \multirow{2}{*}{$\begin{array}{l}\text { Esocids } \\
\text { examined }\end{array}$} & \multicolumn{2}{|c|}{ Alpha (a) } & \multirow[b]{2}{*}{$P$} \\
\hline & & Gizzard shad & Centrarchid & & Gizzard shad & Blucgill & \\
\hline $31 \mathrm{Jul}-10 \mathrm{Aug}$ & 6 & $\begin{array}{c}6.17 \\
( \pm 3.61)\end{array}$ & $\begin{array}{c}0.20 \\
( \pm 0.02)\end{array}$ & 119 & $\begin{array}{c}0.91 \\
( \pm 0.17)\end{array}$ & $\begin{array}{c}0.09 \\
( \pm 0.17)\end{array}$ & $<0.001$ \\
\hline 16 Aug-28 Aug & 4 & $\begin{array}{c}6.80 \\
( \pm 2.99)\end{array}$ & $\begin{array}{c}0.22 \\
( \pm 0.06)\end{array}$ & 229 & $\begin{array}{c}0.98 \\
( \pm 0.11)\end{array}$ & $\begin{array}{c}0.02 \\
( \pm 0.11)\end{array}$ & $<0.001$ \\
\hline $10 \mathrm{Scp}-20 \mathrm{Sep}$ & 8 & $\begin{array}{c}10.67 \\
( \pm 2.57)\end{array}$ & $\begin{array}{c}0.04 \\
( \pm 0.01)\end{array}$ & 51 & $\begin{array}{c}1.00 \\
( \pm 0.00)\end{array}$ & $\begin{array}{c}0.00 \\
( \pm 0.00)\end{array}$ & $<0.001$ \\
\hline
\end{tabular}

contribute to the costs of predation, because removal of prey spines reduces handling times (Hoogland et al. 1956; Gillen et al. 1981).

There was no cover for fish in our experimental tanks, and the presence of vegetation could modify both esocid and prey behaviors. In experiments with northern pike preying on fathead minnows and bluegills, Savino and Stein (in press) and Mauck and Coble (1971) found that prey vulnerability did not change with the absence or presence of cover, but did change with prey species. Northern pike also remained ambush predators regardless of vegetation density (Savino and Stein, in press). Based on these results, it is likely that the patterns of differential prey vulnerability and esocid behaviors we observed can be extrapolated to natural situations with cover.

From our laboratory experiments and the previous work of others, we predicted how esocids should grow in systems with different prey types. Hart and Connellan (1984) observed that northern pike growth was negatively correlated with the time spent capturing each gram of prey. Optimal foraging theory predicts that prey with the highest benefits per cost to a predator will yield the fastest predator growth rates (Pyke et al. 1977). In our experiments, the benefit of bluegills to esocids, in terms of caloric content (as determined by Minton and McLean 1982 and Strange and Pelton 1987), was the lowest and the cost of bluegills (as measured by time to capture) was the highest among the three prey species. Thus, esocids should grow most poorly in centrarchid-dominated systems, which they did. Previous work has documented poor growth of tiger muskellunge with only bluegills as prey compared to their growth in systems where gizzard shad (Goddard and Redmond 1978; Carline et al. 1986; Newman and Storck 1986) or fathead minnows (Gillen et al. 1981; Tomcko et al. 1984) occurred. The density of small bluegills in Tobin's Pond was extremely high; esocid growth in systems with more normal bluegill size distributions might be even lower. Tomcko et al. (1984) found food consumption of tiger muskellunge decreased dramatically when bluegill densities were below $5 \cdot \mathrm{m}^{-2}$.

Available prey influenced not only growth but survival of esocids; survival was lower in the centrarchid-dominated system than where gizzard shad were present. Similarly, Beyerle (1978) observed lower survival for northern pike feeding on bluegills than for northern pike feeding on fathead minnows in lakes. Tobin's Pond was smaller than North Reservoir and differences associated with system size may influence survival. However, Carline et al. (1986) observed good growth and survival of tiger muskellunge in a similar small pond (Worthington Pond, Ohio) when gizzard shad were present, and mortality of this hybrid due to predators and thermal stress at stocking were low. We stocked large $(>205 \mathrm{~mm})$ esocids to reduce losses to resident predators (Stein et al. 1981) and stockings were completed after the temperatures $\left(\leq 25^{\circ} \mathrm{C}\right)$ had declined to levels where potential losses to thermal stress were low (Mather et al. 1986). In addition, by directly pumping largemouth bass stomachs, we estimated that losses of esocids to predation were negligible in Tobin's Pond (Wahl and Stein 1984). Given these assessments of other potential sources of mortality, prey availability appears to have been the principal factor influencing survival of esocids stocked in these systems.

From a management perspective, a variety of factors influence decisions about where esocids should be stocked, including presence of resident predators (Stein et al. 1981), availability of suitable habitat (Dombeck et al. 1986), and presence of appropriate prey (Carline et al. 1986). Previous authors have recommended that, to maximize 
growth and survival, tiger muskellunge should not be stocked in centrarchid-dominated systems, but rather in systems with soft-rayed or fusiform prey, such as cyprinids or shad (Gillen et al. 1981; Moody et al. 1983; Tomcko et al. 1984). We concur with these findings, and extend them to the two parent species.

\section{Acknowledgments}

We thank Tim Nagel (London Fish Farm) and Pat Keyes (Hebron Fish Farm) for providing esocids and bluegills, and D. B. Apgear for coordinating activities with the Ohio Division of Wildlife. Many individuals associated with the Aquatic Ecology Laboratory provided volunteer and technical assistance; in particular the efforts of D. Bryson, K. Bruner, D. Imhoff, J. Farwick, J. Bohne, P. Cunningham, B. Johnson, J. Wahl, L. Einfalt, and $C$. Habicht were critical to this research effort. J. Margraf, G. Mittlebach, J. Bart, D. Coble, and R. Engstrom-Heg critically reviewed the manuscript. This study was supported in part by funds from the Federal Aid in Fish Restoration Act under project F-57-R.

\section{References}

Beyerle, G. B. 1971. A study of two northern pikebluegill populations. Transactions of the American Fisheries Society 100:69-73.

Beyerle, G. B. 1978. Survival, growth, and vulnerability to angling of northern pike and walleyes stocked as fingerlings in small lakes with bluegills or minnows. American Fisheries Society Special Publication 11:135-139.

Beyerle, G. B., and J. E. Williams. 1968. Some observations of food selectivity by northern pike in aquaria. Transactions of the American Fisheries Society $97: 28-31$.

Carline, R. F., R. A. Stein, and L. M. Riley. 1986. Effects of size at stocking, season, largemouth bass predation. and forage abundance on survival of tiger muskellunge. American Fisheries Society Special Publication 15:151-167.

Chesson. J. 1983. The estimation and analysis of preference and its relationship to foraging models. Ecology 64:1297-1304.

Coble, D. W. 1973. Influence of appearance of prey and satiation of predator on food selection by northem pike (Esox lucius). Journal of the Fisheries Research Board of Canada 30:317-320.

Dombeck, M. P., B. W. Menzel, and P. N. Hinz. 1986. Natural muskellunge reproduction in midwestern lakes. American Fisheries Society Special Publication 15:122-134.

Engstrom-Heg, R., R. T. Colesante, and G. A. Stillings. 1986. Prey selection by three esocid species and a hybrid esocid. American Fisheries Society Special Publication 15:189-194.

Foster, J. R. 1977. Pulsed gastric lavage: an efficient method of removing the stomach contents of live fish. Progressive Fish-Culturist 39:166-169.

Gillen, A. L., R. A. Stein, and R. F. Carline. 1981. Predation by pellet-reared tiger muskellunge on minnows and bluegills in experimental systems. Transactions of the American Fisheries Society 110: 197-209.

Goddard, J. A., and L. C. Redmond. 1978. Northern pike. tiger muskellunge, and walleye populations in Stockton Lake, Missouri: a management evaluation. American Fisheries Society Special Publication 11:313-319.

Hart, P. J. B., and B. Connellan. 1984. Cost of prey capture, growth rate, and ration size in pike, Esox lucius $\mathrm{L}$., as functions of prey weight. Journal of Fish Biology 25:279-292.

Headrick, M. R. 1985. Bioenergetic constraints on habitat use by northern pike (Esox lucius) in Ohio reservoirs. Doctoral dissertation. Ohio State University, Columbus.

Hoogland, R., D. Morris, and N. Tinbergen. 1956. The spines of sticklebacks (Gasterosteus and Pygosteus) as a means of defense against predators (Perca and Esox). Behaviour 10:206-236.

Howick, G. L., and W. J. O'Brien. 1983. Piscivorous feeding behavior of largemouth bass: an experimental analysis. Transactions of the American Fisheries Society 112:508-516.

Howland, H. C. 1974. Optimal strategies for predator avoidance: the relative importance of speed and maneuverability. Journal of Theoretical Biology 47:333-350.

Hurlbert, S. H. 1984. Pseudoreplication and the design of ecological field experiments. Ecological Monographs 54:187-211.

Johnson. B. M., R. A. Stein, and R. F. Carline. 1988. Use of a quadrat rotenone technique and bioenergetics modeling to evaluate prey availability to stocked piscivores. Transactions of the American Fisheries Society 117:127-141.

Johnson, L. D. 1969. Food of angler-caught northern pike in Murphy flowage. Wisconsin Department of Natural Resources Technical Bulletin 42.

Mather, M. E., R. A. Stein, and R. F. Carline. 1986. Experimental assessment of mortality and hyperglycemia in tiger muskellunge due to stocking stressors. Transactions of the American Fisheries Society 115:762-770.

Mauck, W. L., and D. W. Coble. 1971. Vulnerability of some fishes to northern pike (Esox lucius) predation. Journal of the Fisheries Research Board of Canada 28:957-969.

Minton, J. W., and R. B. McLean. 1982. Measurements of growth and consumption of sauger (Stizostedion canadense): implication for fish energetics studies. Canadian Journal of Fisheries and Aquatic Sciences 39:1 396-1403.

Montgomery, D. C. 1984. Design and analysis of experiments. Wiley, New York. 
Moody, R. C.. J. M. Helland, and R. A. Stein. 1983. Escape tactics used by bluegills and fathead minnows to avoid predation by tiger muskellunge. Environmental Biology of Fishes 8:61-65.

Neill. S. R. S. J.. and J. M. Cullen. 1974. Experiments on whether schooling by their prey affects the hunting behavior of cephalopods and fish predators. Journal of Zoology (London) 172:549-569.

Newman, D. L., and T. W. Storck. 1986. Angler catch, growth, and hooking mortality of tiger muskellunge in small centrarchid-dominated impoundments. American Fisheries Society Special Publication 15: 346-351.

Pyke, G. H., H. R. Pulliam, and E. L. Chamov. 1977. Optimal foraging: a selective review of theory and tests. Quarterly Review of Biology 52:137-154.

Radakov. D. V. 1973. Schooling in the ecology of fishes. Translated from Russian by H. Mills. Wiley, New York.

Reist. J. D. 1980. Selective predation upon pelvic phenotypes of brook stickleback (Culaea inconstans) by northern pike (Esox lucius). Canadian Journal of Zoology 58:1245-1252.

SAS. 1985. SAS user's guide: statistics, version 5 edition. SAS Institute, Cary, North Carolina.

Savino. J. F., and R. A. Stein. 1982. Predator-prey interaction between largemouth bass and bluegills as influenced by simulated, submerged vegetation. Transactions of the American Fisheries Society 111: 255-266.

Savino, J. F., and R. A. Stein. In press. Behavioral interactions between fish predators and their prey: effects of plant density. Animal Behaviour.
Stein, R. A., R. F. Carline, and R. S. Hayward. 1981. Largemouth bass predation on stocked tiger muskellunge. Transactions of the American Fisheries Society 110:604-612.

Strange, R. J., and J. C. Pelton. 1987. Nutrient content of clupeid forage fishes. Transactions of the American Fisheries Society 116:60-66.

Tomcko, C. M., R. A. Stein, and R. F. Carline. 1984. Predation by tiger muskellunge on bluegill: effects of predator experience. vegetation, and prey density. Transactions of the American Fisheries Society 113:588-594.

Wahl, D. H., and R. A. Stein. 1984. Evaluation of stocking northern pike, muskellunge, and tiger muskellunge into Ohio lakes: a comparative approach. Ohio Department of Natural Resources, Federal Aid in Fish Restoration, Project F-57-R-6, Columbus.

Webb, P. W. 1986. Effect of body form and response threshold on the vulnerability of four species of teleost prey attacked by largemouth bass (Micropterus salmoides). Canadian Joumal of Fisheries and Aquatic Sciences 43:763-771.

Webb, P. W., and J. M. Skadsen. 1980. Strike tactics of Esox. Canadian Journal of Zoology 58:14621469.

Weithman, A. S., and R. O. Anderson. 1977. Survival, growth, and prey of Esocidae in experimental systems. Transactions of the American Fisheries Society 106:424-430.

Received January 15. 1988 Accepted April 16. 1988 